\title{
Mertein Hündsfelder: \\ Fechtlehre mit dem Kurzen Schwert, circa 1491 AD \\ Fight-Teaching with the Shortened Sword from Codex Speyer (137r-141r)
}

\author{
Transcription and Translation by Szabolcs Waldmann, Ars Ensis \\ Copyright 2005- 2013 Szabolcs Waldmann.
}

\section{FOREWORD}

This transcription / translation of mine was first released online in 2005 (Waldmann, 2005 and Waldmann, 2006), and in print in 2008 (Clements, 2008). Since that time we have been using these teachings extensively in our school, in the armoured classes. Together with Marcell Tóth, who is also a trainer in the same class, we have been using this translation as basis for our work; moreover, he wrote his Free Scholler paper from the very same material (Tóth, 2012). Thus, this new release of the article incorporates those seven years of practice and research.

\section{THE CONTEXT OF FIGHTING WITH THE SHORTENED SWORD}

In the $11^{\text {th }}$ century, due to the strength of the newly developed crossbow and the destructive power of impact weapons like the pike and the war hammer, knights began to strengthen their body protection system(Quaas, 1992:10) - which at that time consisted of a padded garment, chainmail armour and helmet - with additional iron, or steel plates. As the longbow, a cheap and high-fire rate projectile weapon appeared by the late $13^{\text {th }}$ c. or early $14^{\text {th }} \mathrm{c}$. (DeVries - Smith, 1958), this progress quickened. What first began as the so called "Coat of Plates", simple sheets of metal sewn into cloth, changed into the full plate armour by the end of the $14^{\text {th }}$ century (Bull, 1991). Though the armour of the mentioned period is still only called the transitional armour, it already protected the body, the limbs and the head with metal plates.

In the time, when the manuscript in question was written, the plate armour was fully developed, and protected the wearer from most harm done by period weapons. Simply cutting at somebody with a sword, who wore such an elaborate defensive system was no longer efficient, to say the least. To thrusting, however, even the most advanced armour of the $15^{\text {th }}$ century was vulnerable. And although rigid thrusting weapons may have pierced the steel plates themselves, the real danger came from the small gaps in the armour, the joints and moving parts. Those were the primary targets in armoured fighting 1 .

The longsword was a wide-spread weapon in Europe at that time. A knightly symbol, a fencing tool, self defense and juristical dueling weapon, it was probably the most

1 On the relation between archery and gunnery see Blair (1958). 
important part of the combat armament of any knight or armoured fighter (Oakeshott, 1964). It is quite effective against unarmoured opponents, but like before said, it poses less threat in itself against plate armour. That is the reason, why the shortened sword fighting, sometimes called "halfswording" 2 by modern practitioners, came into being. In this fighting art, the longsword is grabbed with both hands like a spear, one holding the grip and the other around the middle of the blade, while the usual attacks are generally stabs, and thus the sword is "shortened" 3 . This way of thrusting proves more effective, faster and stronger, and the small gaps of the armour can be found with the point.

Thus the fencing masters of the era clearly divided the unarmoured fencing (Bloßfechten) and the armoured fencing (Harnischfechten) in their manuscripts, and some masters - like Hündsfelder himself - devoted their work solely to armoured fighting.

The treatise of Hündsfelder aside, the fighting with the shortened against plate armour can be seen in a number of other manuscripts as well: the Gladiatoria-group ${ }^{4}$, Hans Czynner $^{5}$, Hans Talhoffer ${ }^{6}$ and Codex Wallerstein ${ }^{7}$, just to name a few.

2 The name "Halfsword" is a loose translation of the german word "Halbschwert" or "Halben Schwert", which is used in many fencing treatises, for example in the so called "Ringeck Fechtbuch" - Dresden fol. 98v - "'Die erst hut In dem halben schwert Item halt din schwert mitt de $\sim$ rechten hand bÿ der händhäbe vñ mitt de $\sim$ lincken grÿff mitten in die clingen vñ halt es neben dine $\sim$ rechten sÿtten über din haüpt vñ laß den ort vndersich hang $\sim$ dem man gegen dem gesicht "). Other examples would include Philippo di Vadi, "mezza mella".

3 See transcription / Translation, fol. 137 of Codex Speyer, MS M.I.29 later in the text.

4 A group including four currently known manuscripts, all from the $15^{\text {th }}$ century: MS KK013 Kunsthistorisches Museum Wien; MS U86.F46, Rare Book and Manuscript Library (Paul Mellon Bequest) of the Yale Center for British Art, New Haven Connecticut; Cod. Guelf 78.2 Aug. $2^{\circ}$, Herzog August Bibliothek Wolfenbüttel and MS CL23842, Musée National du Moyen Age, Paris. See Hils (1987)

5 MS 963, Universitätsbibliothek Karl-Franzers, Graz. See Bergner-Giessauf (2006)

6 Currently 6 originals and 10 copies are known, plus a newly found manuscript from Kassel, Ms.iurid.29 2. Originals: MS Chart. A558, Forschungsbibliothek, Gotha; Hs. XIX, 17-3, Gräfliche Bibliothek, Königseggwald; P 5342 B, Kunsthistorisches Museum, Wien; 78 A 15, Kuperstichkabinett-Preuszischer Kulturebesitz, Berlin; Thott 290 2, Det Kongelige Bibliotek, Copenhagen and Cod. icon 394a, Bayerische Staatsbibliothek, München. \{Membr. 1.no. 114 Cypr. p. 22 LXXV. Herzoglichen Bibliothek, Gotha\}

Copies (mostly mixed with other material as well): MS B 26.Universitätsbibliothek, Erlangen; Codex 5278, Österreichische Nationalbibliothek, Wien; Mscr. S 554, Zentralbibliothek, Solothurn; Pict. A 83, Staatsbibliothek Preussischer Kulturbesitz, Berlin; Cod.I.6.2.1, Universitätsbibliothek, Augsburg; Cod. Vindobonensis Ser. Nov. 2978, Österreichische Nationalbibliothek, Wien; Philos. 61, Niedersächische Staats- und Universitätsbibliothek, Göttingen; Cod. Guelf. 125.16 Extrav, Herzog Augustbibliothek, Wolfenbüttel; Cod. icon 394, Bayerische Staatsbibliothek, München and Cod. icon 395, Bayerische Staatsbibliothek, München. For an introduction, see Schulze (2010).

7 Cod.I.6.4 .2, Universitätsbiblithek Augsburg. See Żabiński and Walczak (2002). 


\section{INTERPOLATION NOTES}

The Fight-teaching with the Shortened Sword by Mertein Hündsfelder (aka Hundfeldt, Hundtfeldtz, Hundßfelder) can be found in the so-called Codex Speyer from 1491, residing at the Library of the University of Salzburg in Austria; it has been described by Jungreithmayr (1988). The codex itself was written by Hans von Speyer', who probably was a fencing master himself (Hils, 1985:114) ${ }^{10}$. He collected teachings of other masters to be included in his fight-book.

Another source, for Hündsfelder's teachings is the so-called Codex Danzigi1, written by Peter von Danzig circa 1452, which features the same text, although ascribed to "Lignitzer"; while completely different text in said codex is ascribed to "Hundtfeldtz". However, the Codex Lew ${ }^{12}$, written by Jud Lew in circa 1450, has equivalent text to Hündsfelder ascribed to "Hundßfelder"; while the latter codex ascribes the text to "Lew" himself equivalent to that differing "Hundtfeldtz" in Codex Danæig, the same text which Codex Speyer, in circa 1491, ascribes to Lew.

So the question arises: Why is the shortened sword fighting by "Hündsfelder" in Codex Speyer different from that of "Hundtfeldtz" but equivalent to "Lignitzer" in Codex Danrig?

The dating of the firstly mentioned two manuscripts would suggest that Danzig would be right, by ascribing the aforementioned shortened sword teaching to Lignitzer instead of Hündsfelder, since Codex Speyer is dated 1491, Codex Danzig 1452, and is thus older. But including Codex Lew into this equation, which is dated also to the 1450s, one can conclude that Codex Speyer probably used Codex Lew as a source ${ }^{13}$ (also considering that it includes a lore ascribed to "Lew", which is also to be found in Codex Lew under the aforementioned name). It is worth noting however that the lore in Danzig (almost equivalent to Hündsfelder via Speyer and Lew, but there ascribed to Lignitzer) is actually much longer and has more material.

This transcription and translation uses Codex Speyer and Codex Danzig, and interpolates the missing parts into a single lore, but with Codex Speyer as basic material. Words in

\footnotetext{
8 MS M.I.29, fol 134r-171r, Universitätsbibliothek Salzburg. For a description, see Jungreithmayr (1988).

9 The name is taken from fol $158 \mathrm{r}$ of the said Codex, which states that "Finis in die vincule Petre Magister Hans von Spier", see Jungreithmayr (1988).

10 Hils quotes a paper from Zürich, dated 1500-1510, in which a fencing master called Meister Hans Freytag von Speyer is named. Hils writes about the possibility that this is the same Speyer, who wrote the Manuscript HS43.

11 Cod. 44.A.8 \{or MS 1449\}, Biblioteca dell'Accademia Nazionale dei Lincei e Corsiniana, Roma. See. Hagedorn (2008), I will refer to this manuscript simply as Danzig, in later footnotes for the interpolation part.

12 Cod. I.6.4 .3, Universitätsbiblithek Augsburg. There is no edition or translation printed. For a description, see Hils (1985:32)
}

13 Or the yet unknown source for Codex Lew itself. 
bold are interpolated from Lignitzer into Hündsfelder (Maziarz, 2006). In case of such parts I will refer to the folios of the Codex Danigg manuscript (in footnotes simply called: Dan₹ig). The reference will always be added to the first interpolated word of a new folio in Codex Danzig, every interpolation that follows is still from the same folio. When a new folio starts, the first word will get the new folio reference.

I transcribed and translated the original manuscript myself from the Codex Speyer. Yet I must thank Monika Maziarz for help from comparison to her Lignitzer transcription; as well as Bartlomiej Walczak, Jeffrey Hull for and Daniel Jaquet for their help during my work.

Since 2008, a new transcription of Codex Danzig is available on the Internet and in Book form, from Dierk Hagedorn (2008).

\section{NOTE ON TRANSCRIPTION AND TRANSLATION}

The original manuscript was written with red and black inks. Using red for some parts of a text normally written in black is called rubrum. It is used to stress important words or indicate headings, and to help learning the text and remembering it as a picture, a technique used very often in manuscriptory (Wenzel, 1995).

In the transcription, the red parts will be written in italic. Words in manuscript and mutated vowels, like ü and $\ddot{y}$ are also replicated. Words in bold interpolations from Lignitzer into Hündsfelder, as already explained.

As for my Translation: Words in [brackets] are not in the manuscript verbatim, but are needed to make sense in English translation. Words in CAPITALS are original German words which I found important to let untranslated. These are found in other fechtbücher as well, and modern HEMA / WMA fencers use them as global terminology, tough no common understanding exists yet, how to execute these techniques or what they mean; so different interpretations exists. Here is an English description of these terms, where I use the most common interpretations:

Indes: In the middle, right as or just as something happens.

Absetzen: off-setting or down-setting, deflecting an attack while harassing the enemy at the same time.

"Inwardly" and "Outwardly" are often used in the verbatim of the lore, this can be confusing. In our ${ }^{14}$ efforts to translate this lore into a teachable curriculum, we came to the conclusion that the "Inside" of the opponent means to thrust between his sword and his left shoulder. The "Outside" of the opponent means to thrust on the left side of the opponent's sword (viewed from the one who thrusts).

Lastly, a translation cannot be free from personal interpretation, so any errors are mine and comments are welcome.

14 Marcell Tóth \& Szabolcs Waldmann 


\section{TRANSCRIPTION \& TRANSLATION}

(137r) Hie heb sich an das kürtz swert in dem kanpff als es meinster mertein hündsfelder gesait batt

Item Nim das swertt bÿ der rechten hant bÿ dem beÿn und mit der lincken griff mitten $^{15}$ in die clingen und ge vast $\mathrm{zu}$ dem man, So müß er schlagen oder stechen, do küm vor und biß rechs pleyb sollichenn und pleib nohenn.

Das erst stuck

Item Stich Im Inwendig zu synen gesicht, wirt er dir daß, So far durch und setz im an außwendig an sin gesicht, wirtt er daß furbaß und stichet dir den ort $a b$, so wind mit dine knopff in uber sin rechte achsell und spring mit dinem rechten peyn hinder sin linckes und wurff in uber ruck.

Ein bruch

Item Wer dir daß thut und hat dir den knaupff an den hals geworffen, so far mit diner lincken hant von unten auff zwischen sinen payden arme vnd begreif yn pey seine rechten arm und schwing dich dan von Im auff din rechten siten und wurff yn uber die hüff.

Item Wan er dir den knopff umb den hals will werffen, So griff mit der lincken hant von dir und griff unter sin rachte hant an daß pyntt und an den knapff und züch den under sich und setz $\ddot{y} \mathrm{~m}$ an mit dyne schwertt wo dü willt.

(137v) Item wen er dir den knaupff begriffen hat, So wind mit düne knaupff von unden auff außwendig umb sin lincke hant und schub mit dine rechten pÿn fursich und stoß in mit diner clingen an sin lincken arm. (137r) Here begins the shortened sword fighting [with longswords] as Master Mertein Hündsfelder has taught.

Note: Take the sword with your right hand by your leg and with your left hand in the middle of the blade and go fast to the man, so he must cut or thrust, you just step in and remain on the right side and stay close [to him].

The first bout

Note: Thrust him inwardly to his face, parries he this, go through [to the other side] and thrust him his face from the outside; yet he parries this and thrusts his point upwards, so wind with your pommel above his right shoulder and spring with your right leg behind his left and throw him on his back.

\section{A breaking}

Note: Someone does this to you, and has his pommel on your neck, so go with your left hand from below between his arms grabbing his right arm and swing yourself to the right from him and throw him over your hip.

Note: When he wants to throw his pommel over your neck, so get his handle or pommel under his right hand with your left hand, pull it downwards and hit him with your sword wherever you wish.

$(137 v)$ Note: If he grabbed your pommel, wind your pommel from below upwards and out, over his left hand and move in with your right leg and hit him with your sword on his left arm. 


\section{Das ander stück}

Item Stich $\ddot{\text { yn }}$ aber ${ }^{16}$ den ersten stich inwendig $\mathrm{zu}$ sinem gesicht und thün $\mathrm{zu}$ dem andern mall als du ÿm aber inwendig $\mathrm{zu}$ dem gesichtt stechen wilt, Indes far durch und satz ÿm uswendig zu sinem gesicht, wen er dir daz werett, so schrit mit dinem rechten pey hinder sine lincks und stos $\ddot{y} n$ mit dem gehultz in sin lincke uchschen und stoß inwendig, so felt er.

Item wo er dir daß thutt, so schrit mit dinem lincken peyn hinder dich und vohe den stoß zwüschen din beyde hant in die clingen und wind mit dem knaupff von unden auff zwischen sein payde $\operatorname{arm}^{17}$ vnd wind mit deine knopf uber $\sin$ lincke hant und spring mit dinem lincken peyn hintter sin rechtes und stoß $\ddot{y} m$ beÿde swertt uber sin hals so hastu ÿm den rück an gewinnen.

[No equivalent by Hündsfelder via Speyer to this "breaking" by Lignitzer via Danzig - so it has been interpolated here.]

Ein wider pruch wider den

Item wer dir paide swert über den halß wil stossen / So stee freyleich still mit deinem rechten pain / vnd lasß dein swert faren pey dem pind / vnd greif mit deinem rechten arm hinden $\mathrm{vmb}$ seinen ruck / vnd ruck yn pey der mitt / So wurfstu in an zweifel

\section{The second bout}

Note: But thrust inwardly to his face once, and the second time you do as if you want to thrust him to the face from inside, yet INDES move in and bind on his face outside; if he counters that, then move in with your right leg behind his left [leg], push him and push his shoulders with your crossbar inwardly so he falls on the ground.

Note: Whenever he does this to you, so move your left leg behind yourself, catch his push between your hands on the blade, wind your pommel from below upwards between both his arms and wind your pommel over his left hand and jump in with your left leg behind his right [leg], push both swords on his neck so you have him on his back, in a winning position [for you].

[No equivalent by Hündsfelder via Speyer to this "breaking" by Lignitzer via Danzig - so it has been interpolated here.]

Another breaking for this.

Someone wants to put both swords over your neck, so stay open with your right leg and let your sword glide by the handle and grab around his back with your right arm and throw him over without doubt.

\footnotetext{
16 Danzig folio $73 \mathrm{v}$

17 Danzig folio $74 \mathrm{r}$
} 


\section{Das drÿtt stück}

Item Stich im aber zu sinem gesicht inwenig und far in den andern und stich $\ddot{y} m$ ußwendig zu sinem gesicht, wirtt er dir daß aber, So schub mit dem lincken peyn zwüschen sin beÿde hende und griff mit dine knaupff außen uber sin linckes peyn in sin knÿepug und leg dich mit diner lincken achsell oben fast umb yn und hebe unten fast auff und truck auff sinen lincke sytenn.

(138r) Item Wer dir mit dem knaupff will faren in die knÿebug, dem griff mit diner lincken hant hintter sin lincke hant bÿ dem arm und griff mit diner rechten von unten auff $\ddot{y} m$ an den elnbogen und das din finger oben sten, so wuerfftu yn auff daz antlutz ${ }^{18}$.

Die vierde stück

Item Wen dü ÿm Inwendig zu dem gesicht stichest und er dir wider, so gang oben auff sin swertt und begriff sin schwertt py der clingen in die hant und setz indeß den ort an unter sin lincke uchsen, wertt er $\operatorname{dir} \mathrm{da}$ und begrifft din swertt auch als du das syn hast, so arbeÿtt auß eyne riessen als hernach geschriben statt auß wellichem du wild

\section{Das erst reissen}

Item Stich Im Inwendig zu sinem gesicht und wind aber mit dem knaupff auff din lincke siten von unden auff uber sin clingen zwischen siner hant, reiss aber vast an dich, stich ym zü synem gemecht, wertt er dir daz und foch dir daz schwert und du daß sin, daz beyd swert gefangen syn, So würff din swert mit dem knaupff $\ddot{y} m$ In sin rechte siten und spring mit dinem

\section{The third bout}

Note Thrust him inwardly in his face and move to the other one and thrust him to his face from the outside; yet parries he this, then shove with your left leg between both his hands and grab his left leg with your pommel from outside inside his kneejoint and lay at him with your left shoulder, above fast around him, and lift him up from below with intent, and press him on his left side.

(138r) Note: Someone wants to push his pommel in your knee-joint, so grab his arm behind his left hand with your left hand and grab with your right [hand] his elbow so that your fingers look up, so you may throw him on his face.

\section{The fourth bout}

Note If you thrust him inwardly to the face and he does the same to you, go up on his sword and grab his blade and thrust your point INDES under his left shoulder; yet parries he this and grabs your sword just like you did, then work from a wrenching like it is written hereafter choosing the one you like.

\section{The first wrenching}

Note: Thrust him inwardly to the face, but this time wind up your pommel from your left side over his blade between his hands, rip him fast to yourself, and thrust to his groin; yet parries he this, and fights you so both swords become locked in one another, then let your sword fall with your pommel under his right side and spring with your right leg under his left [leg] and 
rechten peyn under sin linckes und nÿm den rück und heb $\ddot{\text { yn }}$ eine ${ }^{19}{ }^{19}$ tzwerchen fingerß hoch auff von der erden und schlag In mit dinem rechten fuß außwendig an an sinen rechten enckel und wurff $\ddot{y} n$ auff $\sin$ rechte syten

\section{(138v) Das ander reissen}

Item Stich ÿm Inwendig zu dem gesicht, wirtt er dir daz und setz dir den stich ab, So wind mit dinem knaupff von unden auff din lincke siten von oben nider in sin swertz clingen zwischen sin beyden hende und tüßt an dich, So rieß im sin lincke hant von der clingen und stich ÿm dan zu dem gemecht, ist er dir zü starck, daz du im die hant vom dem swert nit geriessen magst, So wind mit dinem knaupff aber von unden auff, auff din rechte siten uber sin lincke hant und stos ÿn mit der clingen in sin lincke siten, hauw von dir dan.

Das tritt reissenn

Item Dün im glich als oben geschreben stott und ob beyde swert gefangen wern, So würff ÿm aber sÿn knaupff in sin rechte siten und spring mit dinem rechten peyn hinder sin lincke und griff im mit diner rechten hant in syn peyde ars backen und grif mit diner lincken hant von unten auff $\ddot{y} m$ an sin kÿnbacken und zuch unden an dich und stos oben von dir, so felt er an den rück.

Der vierde bruch

Item Wer dir mit der lincken hant fert under din kÿnbacken und nÿmpt dich mit siner $^{20}$ rechten hant peÿ dem lincken arßbacken und wil dich uber rück werffen, take his back and lift him up with crossed fingers from the earth, and hit him with your right foot from outside to his right ankle and throw him in his right side.

The second wrenching on the second side. (138v) The second wrenching

Note: Thrust him inwardly to the face; yet parries he this by ABSETZEN of your thrust, then wind your pommel from your left from below downwards on his blade between his hands and pull him to yourself, rip his left hand from his blade, and thrust him to the groin; yet if he is too strong, so you cannot get his hand from his blade, then wind your pommel from below upwards on your right side over his left hand and push him in his left side with your blade, and hit him continuously.

\section{The third wrenching}

Note: Do [to] him what is written above, and if both swords were locked, then throw his own pommel into his right side and jump with your right leg behind his left [leg] and hold fast his arse with your right hand and get his face with your left hand, pull him below to you and push him above from you, so that he falls on his back.

\section{The fourth breaking}

Note: Someone has your face with his left hands and your arse with his right hand, and wants to throw you on your back, so get his left hand's fingers with your left 
So griff mit diner lincken hant $\ddot{y} m$ auff sin lincke und griff in bÿ den fingern und prich $\ddot{y}$ die hant auff din lincke siten und var mit diner rechten hant an sin lincken elnbog[e] und nÿm ÿm daz gewiechtt.

(139r) Daß vierd reÿssen

Item Ist aber das peÿd schwertt gefangen sin, würff $\ddot{\mathrm{y} m}$ aber din knaupff in sin rechte siten und spring $\ddot{\mathrm{y} m}$ mit dinem rechten peyn hintter sin linckes und begriff $\ddot{y} n$ mit diner lincken hant hinder seiner lincken hant peÿ dem arm und griff mit diner rechten hant $\ddot{y} n$ beÿ sinem elnbog[e] und nÿm Im daß gewiecht.

\section{Das fünfft reyssenn}

Item Wan er din swertt gefangen hat und du daz sin, so ge durch beyde swert auff din lincke siten, so windestu ÿm sin swert auß daz ers dir also loßen müß, behelt er dan sin swertt und lest dir daz din, So tün sam dü ÿm zu dem gemecht stechen wolst, wertt er dir daz und griff mit siner lincken hant noch dem swertt, So stich unten durch durch sin swert auff sin rechte siten $\ddot{y} m$ uber $\sin$ rechten arm an sin rechte prust, So prichstu $\ddot{\mathrm{y}} \mathrm{m}$ sin swert auß siner hant, So wurff sin swert mit dem ortt gegen ÿm und mit dinem swertt vall in die obern hütt.

Ein bruch

Item Wer dir daz thütt und dir dürch peÿden swertt lauffen will, Stoß ÿm beyde swertt uber den hals und mach die scher.

Ein wider brüch

Item Wer dir die scher hat gemacht, so griff mit diner rechten hant von untten auff hintter sin rechten in daß peyn, daß den negell und den fingern $(139 v)$ oben sten und würff den din swertt fast von dir auff din lincke siten und ker dich gegen $\ddot{y} \mathrm{~m}$, auch auff din lincke siten und wend mit dinem knopff aussen uber sin rechte hand, breaking his hand on your left side and go with your right hand on his left elbow and take his weight.

\section{(139r) The fourth wrenching}

Note: Both swords are locked, so let your pommel fall to his right side and spring with your right leg behind his left [leg], and grab his arm behind his left hand with your left hand, and with your right hand take his elbow and take his weight.

\section{The fifth wrenching}

Note: If he locked your sword and you have his, then go through both swords on your left side, so you wind his sword from him so he must let go, and if he has his own and you have your own, then do as if you would thrust him to the groin, so that he parries and yet again wants to take hold on your sword, so thrust below and through, through his sword on his right side over his right arm to his shoulder so that you break his sword from his hand, and thrust him with his own sword while going into high ward with your sword.

\section{A breaking}

Note: Someone does this to you and wants to run through with both swords, so push both swords over his neck and do the scissors.

\section{Another breaking}

Note: Someone has done this scissors to you, so grab from below behind his right leg with your right hand so that your fingers look $(139 \mathrm{v})$ up, and let the point of your sword fall fast to your left side before you, and meet him from your left side and wind your pommel from outside over his right hand and hit him with your pommel 
hant und schlag $\ddot{y} n$ mit dem knaupff und mit dem gehultz, wo dü willst.

Das sechst reyssenn

Item Wen die schwertt beyd gefangen sint, so wurff den knoupff fast von dir auff dine rechte siten und auff sin lincke site und spring mit dinem rechten peyn hinter sein linckes und griff mit diner rechten 21 hant von unten auff $\ddot{y m}$ In sein rechte uchsen und heb mit seinem swertt uber sich, So wurfftu yn auff dein rechte syten, daz ist daz best und daz lest under den reÿssen.

Das ist ein stück

Item Sticht dir eyner zu dem gemecht, so stich $\ddot{y m}$ auch zu dem gemecht einen stich, den andern stich von oben nider auff sin lincke hant zwischen sein beyden armen und wind mit dem knopff von unten auff $\ddot{y} n$ sin rechte siten, Schrit mit dinem rechten peyn hinter sin linckes und wurff in uber die rück.

Ein brüch

Item wer dir daß $\mathbf{~}^{22}$ thutt so loß din swertt gen peÿ der clingen und begriff mit diner lincken hant hinten vber sin schultern und begriff din swert wider bÿ der clingen und druck yn vast zu dir und schwing dich von ÿm auff din rechten sÿtenn.

\section{(140r) Ein stück}

Item Arbeÿt er mit dir hoch und stich dir zu dem gesicht, so stich von unten auss zwischen sinen beÿde armen und uber sin lincke achsell, begriff $\ddot{y m}$ mit diner lincken hant hintter seyne lincke und wurff din schwert mit dem pyntt auff din lincke achsell und griff mit diner rechten ym yn sin lincken elnbogen, stoß vast von unten auff und nim daz gewichtt, so plybt daz swert under seynem lincken arm zwüschen uwer peÿden. or hilt wherever you wish.

The sixth wrenching

Note: If both swords are locked, then let your pommel fall fast from your right side to his left side and spring with your right leg behind his left [leg] and grab from below upon his right shoulder with your right hand and lift up with his sword so you will throw him on your right side. That is the best and the last of the wrenchings.

This is a piece

Note: Somebody thrusts you to your groin, so thrust him to his groin as well, the second thrust being downwards to his left hand between both his arms, and wind up your pommel from below to his right side, place your right leg behind his left [leg] and throw him to the ground.

\section{A breaking}

Note: If somebody does this to you, then let go of your sword's blade, grab with your left hand around his shoulders and grab your blade again, and press him fast to yourself, while swinging to your right side.

\section{(140r) A piece}

Note: If your enemy works high with you and he thrusts to your face, so thrust from below between both his arms and over his left shoulder, grab him with your left hand behind his left [hand] and throw your sword's handle upon your left shoulder, and with your right [hand] grab tightly his left elbow, push fast upwards and take his weight, so the sword stays under his left arm between you both. 


\section{Aber ein stück}

Item Arbeit er aber hoch mit dir, so stich aber unten auff zwuschen sinen beÿde armen und loß din lincke hant varn von der clingen und griff oben zu uber $\operatorname{sein}^{23}$ swertt riesch und begriff din swert wider bÿ der clingen und stos ÿm beÿde swertt ube den hals hinten uber sin rück gar ab hÿn $\ddot{y} n$ sein beÿd knÿebug und reiß vast untten an dich und mit dem haupt stoß vast vob dir, so wurfftu $\ddot{y} n$ auff den ruck.

Ein bruch dar wider

Item Wer dir daz thün will und will dir die beÿde swert uber den hals stoßen, so far mit diner rechtenn hant in sein lincke siten uber sin ruck und schrit mit dinem rechten peyn vorn fur sein linckes peÿn und würff yn uber die hueff, der bruch gett zu beÿde site zü.

(140v) Ein stück

Item Stich ÿm Inwendig zu dem gesicht und begriff dan syn swert peÿ der clingen $z u$ deinem swertt in din lincke hant und windt mit dinem knaupff von unten auff uber sin rechte hant und heb dan vast uber sich und reiß den auff din rechte siten, So blytt dir sein swert auff dem rechten arm, das ist daz swert nemen

Aber ein stück

Item Wan dü ÿm ÿn lauffest, so stich ÿm ußwendig zud sinem gesicht und griff mit dÿner lincken hant $\ddot{y m}$ zwuschen sin pey peyd hend in sin swertz clingen und loß dan din swert vallen und griff mit diner rechten hant hintter sin lincke ${ }^{24}$ auch in syn swert clingen und druck mit diner rechten hant sein swert vast zu dir in din
Another bout

Note: If he works high with you, then thrust upwards between both his arms and let your left hand glide off the blade and grab it again by the blade after you locked his sword, and push both swords over his neck or even in his back down right to the knee-joints, and rip upwards fast with the head pushed fast from you, so he falls to the ground.

\section{Yet another breaking}

Note: If somebody wants to do this to you, and wants to put both swords over your neck, so go with your right hand to his left side over his back, step in with your right leg forward of his left leg, and throw him over your hip. This break goes to both sides this way.

(140v) A piece

Note: Thrust him inwardly to the face, and then grab his sword on the blade with your left hand and wind your pommel upwards over his right hand, lift him fast upwards, and rip him to your right side, so his sword stays upon the right arm. This is the sword-taking.

\section{Another bout}

Note: If you are running inside to him, then thrust inside to his face and take his blade with your left hand between both his hands and let go of your sword and grab his blade behind his left hand and press his sword with your right hand fast to yourself to your right side, then grab with your left hand downwards between 
rechte syten, So griff dan mit diner lincken hant von oben nÿder zwischen sin beyde arm, ym hinder sein rechte hant in sein pint / vnd wind denn mit seinem chnopf von vnden auf zwischen sein paide arm so nÿmpsteu Im daz schwert.

Ein wider brüch

Item Wer dur daß thutt und dir daz swert will nemen und auß winden will so greif mit dyner rechten hant hinder sin rechte und mit dÿner lincken hintter sin rechten elnbogen, So gewinstu Im den rück ann.

\section{Aber ein stuck}

Item Wan ir beyde umb ey swert umb ein schwert kryegt, So tracht daz dü habpst din lincke hant hintter (141r) sÿner rechten in sÿnem bÿndt und din rechte hantt zwüschen seinen beÿden hende in sÿns schwerts clingen, So begriff ÿn dan mit dÿner lincken hant hinder yn sÿncs rechte und griff dan mit dyner rechten von unten auff sein rechten arm und schrÿtt mÿt dynem rechten peÿn hÿnder synen lÿnckes, zück er das pein hinder sich, so schrÿtt zwüschen sÿn beyde peyn und stos ÿn dan sÿn arm mit diner lincken hant von dir auff din lincke sytenn und zuch $\ddot{y} n$ mit der rechten sÿn rechte arm vast an dich und ein wenig uber sich uff din rechte sÿtenn so feltt $\mathbf{e r}^{25}$.

Finiß. 1

In vigilia Maria Magdaglena 149i. both his arms, behind his right hand on the handle, and wind his pommel between both his arms from below. So you take his sword.

\section{Another breaking}

Note: Someone wants to do this to you and wants to take your sword and wind on you, so take him behind his right [hand] with your right hand, and with your left [hand] behind his right elbow, and so you win his back.

\section{Another bout}

Note: If you both wrestle over a single sword, then strive to have your left hand behind (141r) his right [hand] on his handle, and your right hand between both his hands over his sword's blade; then grab with your left hand behind his right [hand], and with your right [hand] from below upon his right arm and step with your right leg behind his left [leg]; yet steps he back with his left [leg], then step between both his legs and push his arm from you with your left hand then on your left side, and pull his right arm with your right [hand] fast to you and a bit upwards on your right side. So he will fall.

The End. 1

Upon the Eve of Mary Magdalene in 1491.

25 Danzig folio 78r. The text, ascribed to Lignitzer in Codex Danzig, continues for 3 more folios until 79v. These section introduces the Mordschlag in 4 different pieces and a number of breakings against these. In this pieces one would reverse the grip on the sword, holding it by the blade with bost hands, and hitting the opponent with the pommel or the crossbar, like a pollaxe. But these parts are completelly missing from Speyer, and are thus not part of this article. 


\section{BIBLIOGRAPHY}

BERGNER, U. and GIESSAUF, J. (2006): Würgegriff und Mordschlag: die Fecht- und Ringlehre des Hans Czynner (1538): Universitätsbibliothek Graz, Ms. 963. Akademische Druck- u. Verlagsanstalt, Graz.

BLAIR, Claude : (1958) European Armour: Circa 1066 to Circa 1700. Macmillan, London.

BULL, S. (1991) A Historical Guide to Arms \& Armour. Facts on File, New York

CLEMENTS, J. (2008): Masters Of Medieval And Renaissance Martial Arts: Rediscovering the Western Combat Heritage. Paladin Press, Boulder.

DEVRIES, K. - SMITH, R. D. (2012) Medieval Military Technology. revised edition (first ed. 1992), University of Toronto Press, North York, 2012, pp.32-40.

HAGEDORN, D. (2008) Peter von Danzig: Transkription der Handschrift 44 A 8. Online: http:// www.hammaborg.de/en/transkriptionen/peter von danzig/index.php, retrieved the 25.03.2013.

HILS, H-P. (1985) Meister Johann Liechtenauers Kunst des langen Schwertes, Peter Lang Verlag, Frankfurt ; New-York.

HILS, H-P. (1987) Gladiatoria: Über drei Fechthandschriften aus der ersten Hälfte des 15. Jahrhunderts. In Codices manuscripti 13. pp 1-54.

JUNGREITHMAYR, A. (1988): Die deutschen Handschriften des Mittelalters der Universitätsbibliothek Salzburg. Wien, Verl. der Österreichischen Akademie der Wissenschaften. pp.5-7.)

MAZIARZ, M. (2006) Transcription of Codex Danzig: Liegnitzer. Online, http://www.arma.lh.pl/zrodla/traktaty/vond/lignitzerkurtzesschwert.html, retrieved the 25.02.2005. (no longer available).

OAKESHOTT, R. E. (2006) The Sword in the Age of Chivalry. First ed. 1964. The Boydell Press, Woodbridge.

QUAAS, G. (1992). Eisenkleider. Deutsche Historische Museum, Berlin.

SCHULZE, A. (2006-2007): Mittelalterliche Kampfesweisen. 3 volume. Ph. von Zabern, Mainz

SCHULZE, A. (2010): Der Königsegger Codex: die Fechthandschrift des Hauses Königsegg. Ph. von Zabern, Mainz.

TÓTH, M. (2012). FS Shortened Sword Fighting of Mertein Hündsfelder, Győr. Online: http://library.sg18.net/Files/Szakdolgozatok/FS szakdolgozat Toth Marcell.pdf, retrieved the 25.03.2013.

WALDMANN, Sz. (2005): Mertein Hündsfelder: Fechtlehre mit dem Kurzen Schwert. FightLesson with the Shortened Sword from Codex Speyer circa 1491 AD. Onine: http://www.thearma.org/Manuals/hundsfelder.html. Retrieved the 21.01.2013.

WALDMANN, Sz. (2006): Mertein Hundsfelder transcription and translation. Online: http:// www.hemac.org/index.php? site=translations - downloaded 21.01.2013

WENZEL, H. (1995) Hören und Sehen, Schrift und Bild: Kultur und Gedächtnis im Mittelalter. C.H. Beck, München.

ŻABIŃSKI, G., WALCZAK, B. (2002): Codex Wallerstein: a medieval fighting book from the fifteenth century on the longsword, falchion, dagger, and wrestling. Paladin Press, Boulder. 